\title{
State Duties of Protection ANd Fundamental Rights
}

Professor Dr Christian Starck, University of Göttingen

\section{State Duties of Protection in the Constitutional State}

\subsection{The Concept of Duties of Protection}

Duties of protection are duties of the state to protect certain legal interests of its citizens. In particular, they cover the interests of life, health, freedom and property; they do, however, also protect some other interests and certain constitutionally recognised institutions. These duties of protection appear in various guises: as obligations on federal and Länder legislatures, as executive duties to give effect to protective laws (including those which check the exercise of executive discretion), and as guidelines, both for the (constitutional) judicial control of various legislative and executive acts and omissions ${ }^{1}$ and for judicial decision-making in cases at civil law.

The relationship between duties of protection and fundamental rights requires closer examination.

(a) The text of the Basic Law grants a fundamental right of claim - a personal right on a constitutional level in respect of those fundamental rights which the state must not only respect, but which it is explicitly required to protect.

(b) If, on the other hand, we look at fundamental rights as objective values of the legal system in order to create constitutional duties of protection, we should be content to understand them simply as functions of the state, rather than legal duties, which do not give rise to corresponding civil rights. We would need to do this to preserve the difference between the objective aspects of fundamental

$1 \quad$ Alexy Theorie der Grundrechte 410 ff; Robbers Sicherheit als Menschenrecht 125; Stern Das Staatsrecht der Bundesrepublik Deutschland $950 \mathrm{ff}$; in detail Dietlein Die Lehre von den grundrechtlichen Schutzpflichten 70 ff; Unruh Dogmatik der grundrechtlichen Schutzpflichten $20 \mathrm{ff}$. 
rights and the explicitly established, constitutionally protected fundamental right of claim.

(c) Nevertheless, individual rights have been created as a completion of the objective dimension of fundamental rights through reference to the "primary significance" of fundamental rights as individual rights. ${ }^{2}$ The Federal Constitutional Court's Second Senate decided in a case concerning the protection of human life that:

... a failure to heed these duties of protection automatically infringe the fundamental right in Art. 2 II 1 GG. The injured party can protect himself against this with the Constitutional Complaint.

The first senate has followed this judgment. ${ }^{3}$

The fact that state duties of protection have been considered in connection with fundamental rights and have found their legal anchor there can only be explained by the fact that fundamental rights have, over time, become the fulcrum of German constitutional law. Fundamental rights with their various functions have cast their spell over all remaining constitutional law - and, indeed, over almost all of the remainder of the law. They illuminate, saturate and mould the law. In Germany, fundamental rights play a role that they play in no other country, and one can justifiably claim that these rights are central to the entire theory and practice of the law.

\subsection{Historical aspects of the constitutional state}

A short reminder of the foundations of modern constitutionalism and attendant constitutional procedures is essential if we are to develop guidelines for a constructive critique of the jurisprudence of the Constitutional Court. No development in the

2 BVerfGE 50, 290, 337.

3 BVerfGE 77, 170, 214 (2nd Senat) - Stockpiling of chemical weapons; 79, 174, $201 \mathrm{ff}$ (1st Senate) - Traffic noise. 
doctrine of fundamental rights should occur without a glance at the recent history of our European neighbours.

\subsubsection{France}

The 1789 French declaration of human and civil rights describes the goal of every political organisation (i.e. the purpose of the state) as the maintenance of the natural and inalienable rights of man. The rights listed are the rights to freedom, property, security and resistance to oppression (Art. 2). ${ }^{4}$ The French declaration is a traditional formulation of fundamental rights. According to Montesquieu, 5 civil political freedom is the peace of mind that grows from the assurance of one's own security. To achieve this freedom, government must be so arranged that no citizen has cause to fear another. In other words, security is the factual prerequisite of freedom. ${ }^{6}$ Montesquieu's theory found echo in the French constitution of 1793, which made it plain that security is not only a right which obtains against the state: instead, it consists in the protection which the state (la société) gives to all its members for the maintenance of their persons, rights and property. ${ }^{7}$ At the end of the declaration of 1789 , the guarantee of rights against third parties is again referred to along with the separation of powers as one of the preconditions for a constitutional state. ${ }^{8}$

As we know, the Declaration of Human Rights and its reiteration in the French constitutions $^{9}$ which succeeded it was, until our own times, treated only as a legislative programme. Only since 1971 has the Conseil Constitutionnel, prompted by the preambles to the 1958 and 1946 constitutions, derived fundamental rights from

4 On the significance of "sûreté" in the development of the declaration cf Isensee Das Grundrecht auf Sicherheit $14 \mathrm{f}$; on its significance in present French constitutional law: Luchaire La protection constitutionnelle des droits et des libertés 42 f, $341 \mathrm{ff}$.

5 Montesquieu De l'esprit des lois chap 6, cited analog to edition Gonzague Truc (Classiques Garnier), "La liberté politique dans un citoyen est cette tranquillité d'esprit qui provient de l'opinion que chacun a de sa sûreté; et pour qu'on ait cette liberté, il faut que le gouvernement soit tel qu'un citoyen ne puisse pas craindre un autre citoyen."

6 Thus, Isensee Das Grundrecht auf Sicherheit 7: "Locke's philosophy of freedom does not replace Hobbes' philosophy of security. Rather, it builds on it and develops it."

7 Art 8. Thus, later, Part VIII of the Preamble to the Constitution of the Second French Republic (1848): "La République doit protéger le citoyen dans sa personne, sa famille, sa religion, sa propriété, son travail, ...".

8 Art 16.

9 In connection with security cf art 8 of 1793 Constitution, art 4 of 1795 Constitution, Preamble Sec VIII of 1848 Constitution. 
the Declaration. Since these are used as guidelines for the preventive control of legislation, ${ }^{10}$ the Conseil has not needed to answer the question whether these fundamental rights should be characterised as individual rights in contradiction of the tradition of French droit public. The Conseil Constitutionnel treats the protection of personal security and property as a constitutional principle, not a right. In recent French writings, the maintenance of security as against third parties is regarded as a state duty, ${ }^{11}$ and the jurisprudence of the Conseil Constitutionnel is summarised thus: not only does the court assess whether the statute has achieved the necessary balance between security and freedom, but it also examines whether the legislature has gone too far in limiting freedom. The rules which the constitution permits the legislature to pass in order to maintain public order may not be more restrictive than is necessary to guarantee the exercise of any one freedom. The preeminence of security, which is referred to first, is noticeable; only secondarily is the (relatively new) question raised as to the necessity of the infringement of freedom - in German terms, whether the infringement is proportional. The French tradition of expressing droit public solely in terms of objective principles makes an account of the function of the state in preserving public security straightforward. ${ }^{12}$

\subsubsection{Germany}

Through the mid-19th century and beyond, freedom and security were also regarded as state objectives in Germany. This was prompted by the rationalist philosophy and legal theory of the time. According to Kant, the state had to preserve security through the creation of laws. In the Metaphysic of Morals, ${ }^{13}$ he states:

10 Cf with further references Starck 1988 Archiv des öffentlichen Rechts 632, $633 \mathrm{f}$. Regard must be paid to the fact that the Conseil Constitutionnel can only decide if it has a draft statute before it. A legislative omission can be considered, however, if a statutory regulation is repealed, and the repealing statute is laid before it.

11 Luchaire La protection constitutionnelle des droits et des libertés $341 \mathrm{f}, 367 \mathrm{ff}$, also on the whole topic, citing the decisions of the Conseil Constitutionnel of 27 July 1982 and 3 September 1986, where the balance between freedom and security is expressly tied to art 4 of the 1789 Declaration. Cf Recueil des Décisions 1986, 135, 138.

12 Cf Classen 1987 Jahrbuch des öffentlichen Rechts 29 ff; Schlette Die verwaltungsgerichtliche Kontrolle von Ermessensakten 61.

13 Vorländer (ed) Metaphysik der Sitten 186. 
... the state of peace is simply the secured existence under law of Mine and Yours in a group of contiguous people, who are thereby bound by a constitution. The rules of this constitution are not drawn from the experience of those who have so far found them most suitable as norms for others, but through the rational a priori from the ideal of a legal association of human beings under public laws.

According to the General Law for the Prussian States (1794),

... each inhabitant of the state is entitled to demand the protection of the same for his person and property. ${ }^{14}$

The law protected the natural human freedom

... to be able to secure and maintain his own well-being without disturbing the rights of others. 15

In part IV of the constitution for the Kingdom of Bavaria (1818), entitled "of general rights and duties", we read that "the state grants each inhabitant security of his person, property and rights". 16

German liberal constitutionalism of the 19th century is rooted in the thought of Kant and the ideas of the Prussian General Law. This is particularly apparent in the article on freedom that Karl von Rotteck wrote for his lexicon in 1847:17

The law will only grant me the freedom it grants to others. Law is none other "than the rationally regulated external freedom, i.e. a freedom protected from internal contradictions, a concept which therefore cannot be separated from the idea of (rational or true) law."

14 General Law for the Prussian States (Intro § 76).

15 General Law for the Prussian States (Intro § 83).

$16 \S 8 \mathrm{sec} 1$. Similar clauses can be found in the Constitution of Baden (1818) § 13, Württemberg (1819) § 24 and Braunschweig (1832) § 32.

17 Von Rotteck and Welcker (eds) Das Staats-Lexicon $183 \mathrm{f}$. 
This consideration gives rise to the following function of the state:

As a legal institution, the state must recognise and protect the freedom of its dependents, as a right intrinsic to them as people in every sphere of human activity. It need not, therefore, grant them these rights initially.

If the state has

... reserved for itself the infringement of the rights of its dependents, it is also obligated to protect these from each other where those rights might be threatened. 18

Among others, Von Rotteck gives the following example: the state must ... govern the ever-present threats to citizens' freedom with wise laws and their careful administration. These threats arise from the abuse of personal and societal power in the home, the family, the local community, the church etc. Similarly, the state must check the specifically criminal threats to freedom represented by kidnapping, abduction, false imprisonment and by deceit and violence of every kind.

Von Rotteck calls this function

... the duty of the state or of the legislature and executive in connection with personal rights, that is, the freedom of the citizenry. ${ }^{19}$

It is fulfilled through the creation and application of civil, criminal and procedural law. This state duty corresponds to a civil claim to justice which is fleshed out by procedural law.

18 Von Rotteck and Welcker (eds) Das Staats-Lexicon 186.

19 Von Rotteck and Welcker (eds) Das Staats-Lexicon 185. 
In 19th century Germany, the guarantee of security through the protection of life and limb, freedom and property was generally conceived as a mere state function. ${ }^{20}$ This function was only matched by individual rights to the extent that the legislature had created such rights, which could then generally be enforced before the courts. The fact that certain authors derived these functions of the state from fundamental rights did not affect their character as bare duties. This is particularly clear from Rönne and Zorn's authoritative work on Prussian constitutional law. ${ }^{21}$ They deny the supremacy of fundamental rights over statute; instead, they mention "so-called" fundamental rights. Nevertheless, state duties are derived from these rights (for example the elimination of serfdom and the protection of citizens from the unjust infringement of their freedom by others). The older concept of state functions is thus maintained, although subsumed by some authors under programmatic ("so-called") fundamental rights.

\subsubsection{England}

The guarantee of security was one duty of the English monarch. ${ }^{22}$ If he or she did not fulfill this duty, there was a natural right of resistance. But there was no corresponding personal right which could be enforced as a claim against the sovereign. Essentially, the right of resistance was a compensating right which could only be justified as a natural right. The transfer of sovereignty to the King in Parliament (1660-1688) placed the duty to preserve security on Parliament. Since no citizen has any individual rights against Parliament, the right to security is respected through statutes passed solely in the discretion of Parliament, and through the case law developed by the courts. The net result is a situation which mirrors that of France and Germany, albeit with a strengthened judiciary. The quasi natural law foundation of the courts' jurisdiction produces a claim to the administration of justice and a guarantee of the application of the laws within the rule of law. ${ }^{23}$ As in France there is

20 Zachariä Deutsches Staats- und Bundesrecht $46 \mathrm{f}$ : "Accordingly, the 'rule of law', 'maintenace of a legal state of peace', 'preservation of the legal order', 'prevention of all illegality', 'protection of natural and acquired rights' are to be the sole and exclusive, or at least the main function of the state." For further references see Hermes Schutz von Leben und Gesundheit 159-165; Robbers Sicherheit als Menschenrecht $97 \mathrm{ff}$.

21 Rönne and Zorn Das Staatsrecht der Preußischen Monarchie 37, 38 f.

22 See Robbers Sicherheit als Menschenrecht 36-50.

23 Dicey Study of the Law of the Constitution $183 \mathrm{ff}$. 
no individual right to security enforceable by the citizen against the legislature in England.

\subsection{Constitutional theory}

The above historical excursus reveals that, despite their very different evolution, a single theory underlies the variety of constitutional states. The development of the constitutional state in the battle with monarchical absolutism gave rise to the overwhelming significance of the preservation of freedom through the maintenance of law and the separation of powers which Article 16 of the 1789 French Declaration described as the precondition for the existence of a constitution. This has given rise to various legal devices, based also in part on experience with moderate rule 24 and earlier theories of the imperium limitatum. ${ }^{25}$

\subsubsection{The separation of powers}

The separation of powers presupposes constitutional regulation of the creation, functions, jurisdiction and procedures of the highest organs of the state. According to constitutional theory, this regulation must be such that it creates checks and balances and effectively secures freedom. Independent courts are essential. But the hindrance and control of state power must not be taken so far as to prevent the state from fulfilling its functions of securing peace, both internal and external, and social justice. Rather, in organising the state for the promotion and protection of freedom, we must seek the right balance of the separation and connection of powers. ${ }^{26}$

\subsubsection{The guarantee of rights}

The first classical fundamental rights were civil and human rights intended to protect citizens against the state, and claims not to be disadvantaged by certain state violations. These rights are either collected in a written code or developed by the

24 Link Herrschaftsordnung und bürgerliche Freiheit 36 ff, 89 ff; Stolleis Geschichte des öffentlichen Rechts $90 \mathrm{ff}$.

25 Von Wolff Jus Naturae methodo scientifica pertractatum 1764 §§ 72 ff.

26 Kägi Dreiteilung zur umfassenden Gewaltenteilung $151 \mathrm{ff}$. 
courts. For the sake of making freedom mutually bearable and to preserve the internal peace of states, these rights can and must be limited. This occurs regularly through state legislation, which might be justified either by explicit constitutional limitation of these rights or by the fundamental function of the state of preserving peace and security. In some codes this is expressed as a right to security. As long as the legislature was seen as the sole guarantor of rights 27 - in France well into the second half of this century 28 - it was sufficient that independent courts could ensure that statutes were correctly - that is, fairly - enforced. But the inner logic of constitutionally-guaranteed rights forces us to conclude that these rights must also be protected against the legislature. The Supreme Court of the USA derived this doctrine in 1803 from the supremacy of the constitution. ${ }^{29}$ This led over a century later to the introduction of special constitutional courts in some European states with jurisdiction to control statutes, thereby protecting individual rights. We must return to this point shortly.

\subsubsection{State functions}

The separation of powers and the protection of rights are the two main features and tools of the constitutional state in the direct and indirect protection of the freedom of the citizen from unjustified infringement by the state. However, the guarantee of freedom must be seen in the light of other state functions, for these give it meaning and practical significance. ${ }^{30}$ We should take especial note of the protection of internal security (peace) and the guarantee of social justice. ${ }^{31}$ While freedom is enshrined in numerous rules governing the separation of powers and the enforcement of rights, these other state functions have not been reflected in specific legal techniques at a constitutional level. They undergird the constitution as important aspects of the

27 Thus, overwhelmingly in 19th century Germany; cf Starck Verfassungsgerichtsbarkeit 11, 32 f; Starck Der demokratische Verfassungsstaat 33, 50.

28 Thus also Duverger and Sfez Die staatsbürgerlichen Rechte in Frankreich 543 ff, 636: Statutes themselves may not be challenged. In practice this is not a serious problem, at least as regards civil liberties, for the National Assembly, as representative of the people, only rarely passes statutes inimical to freedom.

29 Marbury vs. Madison, 2 Law Ed. U.S. 60, 73 (1803).

30 Isensee Das Grundrecht auf Sicherheit 19: fundamental freedom would be valueless, if it was not grounded in security. See further pp $21 \mathrm{ff}$.

31 Starck Frieden als Staatsziel 867, 868 ff; Starck Der demokratische Verfassungsstaat 231, 232 ff. 
legitimation of the state, 32 but references to them in the text of the constitution are, where they exist at all, rather fleeting and unsystematic. They are generally found in such places as the preamble, in clauses concerning constitutional foundations, in the programmatic statements which commonly accompany fundamental rights, in explicit limitations of fundamental rights and in the organisational part of the constitution. 33 This is particularly true for the primary state function of preserving security and peace, ${ }^{34}$ which is the foundation of the state's criminal jurisdiction and for the state's civil justice system, through which life, limb, property and reputation are protected.

\subsubsection{Constitutional jurisdiction}

The review of statutes by a constitutional court for their consistency with the constitution, and, more specifically, the review of fundamental rights which interests us here, is a later development of the constitutional state, at any rate in Europe. ${ }^{35}$ The introduction of judicial control of statutes is historically connected with a conception of fundamental rights as limits to the power of the state, which is made particularly plain by the Amendments to the US constitution (1791): "Congress shall make no law...abridging freedom of speech...".36 In Europe, judicial review of statutes was either introduced alongside a catalogue of primarily defensive fundamental rights ${ }^{37}$ or was explicitly limited by a recognition that these classical fundamental rights alone were the only appropriate standard for review. 38

The court exercising control can decide, using legal techniques, whether a statute violates a classical individual right of freedom and is thus unconstitutional or whether it limits the right in a constitutionally acceptable manner. The court examines whether the statute advances a common interest in a suitable, necessary and appropriate manner or - in the words of the US Supreme Court - by responding to a

\footnotetext{
32 Isensee Das Grundrecht auf Sicherheit 17.

33 Eg art 35 II, and some of the regulations of arts 73 and 74 GG.

34 Isensee Das Grundrecht auf Sicherheit 16; Starck Frieden als Staatsziel 867 ff; Götz Innere Sicherheit 1008 f. For evidences see Hermes Schutz von Leben und Gesundheit 171 ff; Sachs in Stern Das Staatsrecht der Bundesrepublik Deutschland 1733; Klein 1989 NJurW 1633, 1636.

35 Starck Verfassungsgerichtsbarkeit 33.

36 Art 1 etc.

37 Thus in West Germany 1949/1951.

38 See art 18 I Portuguese Constitution; art 53 I, II Spanish Constitution; cf Starck Europas Grundrechte im neuesten Gewand 467, 480.
} 
clear and present danger. In the process, the assumptions of fact and the predictions of the legislature must also be examined, taking into account a certain degree of discretion. 39

Thus, the structure of the classical fundamental rights as defensive rights which limit the power of the state corresponds to the constitutional review of statutes, for judicial review of Acts of Parliament restricts itself to the enforcement of the constitutional limits of political activity. Adjudication remains distinct from politics; the separation of powers is observed. More precisely, what is maintained is the division of function between constitutional court and Parliament, which is grounded in their differing organisation and procedures. 40

\section{Duties of Protection in the Basic Law and according to the Jurisprudence of the Federal Constitutional Court}

Fundamental duties of protection do not conform to the structure of fundamental rights as it has so far been expounded. They require the state, not to refrain from acting, but to take positive action. In the following account we must consider (1) whether and how the Basic Law expressly creates duties of protection, (2) the duties that have been discovered by the Federal Constitutional Court in the Basic Law, (3) the justification for such duties, which is of particular interest, and finally (4) the constitutional control of the manner of protection.

\subsection{Textual analysis of the Basic Law}

\subsubsection{Protection}

The concept of protection can be found explicitly or by necessary implication in the following fundamental rights of the Basic Law:

39 See on this Ossenbühl Tatsachenfeststellungen und Prognoseentscheidungen $458 \mathrm{ff}$.

40 Cf Röllecke and Starck Bindung des Richters 43, 65 ff; Starck Der demokratische 
(a) Article 1 I contains the duty of all state power to protect human dignity.

(b) The protection of youth limits the freedom of communication in article 5 II. Freedom of movement may be limited to protect the young from neglect (article 11 II); infringements of the integrity of the home are permitted for the protection of youth (article $13 \mathrm{VII}$ ).

(c) Article 5 II speaks of a right to personal reputation in the sense of the protection of reputation parallel to the protection of youth. The right to personal reputation as a limit on the freedom of communication thus refers to state protection from injuries to one's reputation by third parties.

(d) The protection of internal security is expressed in article $8 \mathrm{I}$ in that the right granted is the freedom to assemble "peacefully and without weapons". This protection is specifically referred to in the limitations on the freedom of association (article $9 \mathrm{II}$ ), on freedom of movement (article $11 \mathrm{II})$ and on the inviolability of the dwelling (article 13 II - VII).

(e) According to article 6 I, marriage and the family enjoy the particular protection of the state order.

(f) The state's supervision over the parental right of upbringing ought to protect the child from the abuse of this right (article 6 II).

(g) Article 6 IV states that every mother has a claim to the protection and care of the community.

\subsubsection{Guarantee}

When the Basic Law "guarantees" the undisturbed exercise of religion (article 4 II), the freedom of the press and so forth (article 5 I 2) along with property and inheritance (article $14 \mathrm{I}$ ), or when it is stated that art and science are "free", it is 
possible to read the constitution as providing a general, all-round protection. It could be taken as a guarantee against infringements by third parties, and thus a duty of protection could hide behind the guarantee. But we must be careful to not strain the text of the Basic law, particularly since the freedom of private education, for example, is "guaranteed". The expression is generally used to mark the protection of fundamental rights and does not necessarily imply the existence of an immanent duty of protection. 41

\subsubsection{Inviolability}

Freedom of the person (article 2 II 2), freedom of belief and conscience (article 4 I), the privacy of mail and so forth (article $10 \mathrm{I}$ ) and the dwelling (article $13 \mathrm{I}$ ) are declared "inviolable". This classical manner of expressing fundamental rights does not imply duties of protection either, however.

\subsubsection{Conclusions}

The text confirms that constitutional duties of protection seldom correspond to an individual right to protection. To the extent that duties of protection are named as limitations on fundamental rights, they simply represent a power of the state to limit those fundamental rights to protect the named interests. Since such expressions are subsidiary and rather unsystematic, appearing as they do in traditional formulations, we must conclude that duties of protection - certain explicit exceptions notwithstanding - belong to those functions of the state which are a precondition of the constitution and not part of it.

\subsection{Duties of protection adopted by the Federal Constitutional Court}

41 Art 4 II GG is connected with art 135 II Weimar Reich Constitution which explicitly mentioned the protective duty: "The unhindered exercise of religion is guaranteed by the Constitution and rests under state protection. Cf Von Mangoldt Klein and Starck Das Bonner Grundgesetz art 4 marg no 19, 121; in similar fashion art 142 Weimar Reich Constitution required the state to protect art and science. 
The Federal Constitutional Court has now developed state duties of protection in the fields listed below. These duties exist especially, although not exclusively, to protect individuals from each other.

(a) human life, including unborn life; human health (article 2 II 1)

(b) personal freedom (article 2 II 2)

(c) the right of personal development (article 2 I)

(d) the freedom of science, research and teaching (article 5 III)

(e) marriage and the family (article 6 I)

(f) children (article 6 II 2)

(g) mothers (article 6 IV)

(h) the freedom of occupation (article $12 \mathrm{I}$ )

(i) property (article 14 I)

\subsubsection{The protection of human life and health}

The Federal Constitutional Court derives the function of the state in protecting human life directly from article 2 II 1 . In addition, it relies on the guarantee of human dignity in article 1 I 2.42 In deciding on the constitutionality of life imprisonment, the Court emphasized the connection between the protective duty of the state and the general deterrent effect of the criminal law. The elements of murder and the threat of punishment were directly related to the fundamental duty of the state to protect life. ${ }^{43}$ A total separation from the outside world for particularly dangerous prisoners is justified by the need to protect life, ${ }^{44}$ and, in the case of terrorist attacks, the Court has indicated that the duty of protection extends, not only to the individual, but also to the population in general. ${ }^{45}$ In its second decision on the separation of prisoners, the Court relied on an argument concerning the self-preservation of the state, recognising the security of the state as a constituted power for peace and order along with the security of its population which it had a duty to preserve as constitutional values. 46

BVerfGE 45, 187, $254 \mathrm{f}$.

BVerfGE 45, 187, 256; cf also BVerfGE 64, 261, 275 (leave from detention).

BVerfGE 46, 1, 13; 49, 24, 53.

BVerfGE 46, 160, 164. 
The state protects life and health through the law relating to the liability of the medical profession ${ }^{47}$ and its enforcement, ${ }^{48}$ as well as through the restriction of night labour. ${ }^{49}$ Life and limb must also be protected from the dangers of new technology, as the Court has established in many decisions concerning nuclear plants, 50 the health-threatening consequences of aircraft noise,51 the stockpiling of chemical weapons $^{52}$ and air pollution. 53

According to both of the Federal Constitutional Court's Abortion Judgments, the state is obliged to protect unborn human life (article 2 II 1, 1 I 2) from unlawful harm, including that inflicted by the mother. 54 In connection with the protection of life, the Court has commented that the degree to which the duty of the state is to be taken seriously depends on the rank of the relevant legal interest in the Basic Law's hierarchy of values. 55

\subsubsection{The protection of personal freedom}

The state's duty to protect personal freedom (article 2 II 2) from third-party attacks was at issue in a case concerning private liability. While the case could have been resolved constitutionally by applying article 2 I in conjunction with article 20 III on the basis of a breach of the judicial duty to follow the relevant law, 56 four of the eight judges relied directly on the state's duty to protect personal freedom and came to the conclusion that this had to be achieved constitutionally through the application of private liability. 57

47 BVerfGE 52, 131, 167.

48 Cf on this the decision on the enforced clearing of residences BVerfGE 52, 214, 220; 84, $345 \mathrm{ff;}$ BVerfG, 1991 NJurW 3207.

49 BVerfGE 85, 191, 212 f; 87, 363, 386 f.

50 BVerfGE 49, 89, 140 - Kalkar; 53, 30, 56 f - Mülheim-Kärlich; 402 f - Interim atomic waste depot Gorleben.

51 BVerfGE 56, 54, 78; 79, 174, $201 \mathrm{f}$.

52 BVerfGE 77, 170, $214 \mathrm{f}$.

53 BVerfG 14 Sept. 1983 - 1 BvR 920/83, Bayer 1984 Verwaltungsblätter 14; air pollution can also infringe property rights.

54 Thus BVerfGE 39, 1, 42; 46, 160, 164; 49, 24, 53; 86, 390, 395.

55 BVerfGE 39, 1, 42; 46, 160, 164; 49, 24, 53; 86, 390, 395.

$56 \S 823$ BGB. Thus BVerfGE 49, 304, 324 (4 judges).

57 Thus BVerfGE 49, 304, 323 (4 judges); Schwabe 1979 Deutsches Verwaltungsblatt 667 f. 


\subsubsection{The protection of the right to autonomous development of one's personality}

In the Lebach judgment, the Court enunciated the state duty to protect the right to personality of an ex-criminal who was being rehabilitated against media freedom. 58 A state duty to protect against the private processing of personal information can be found in embryonic form in the Data Protection judgment of 1983:

A society and a corresponding legal order in which a citizen could no longer know why and who knew what about him would be inconsistent with the right to informational self-determination. 59

There are many other decisions in third-party effect (Drittwirkung) cases concerning the duty of the state to protect personal development. ${ }^{60}$

\subsubsection{The protection of the freedom of science, research and teaching}

The Federal Constitutional Court has developed the value enshrined in article 5 III into

... a right to such state measures, including organisational measures, as are indispensible for the protection of an area of freedom guaranteed by fundamental rights. It is these measures that make free scientific activity possible at all.

The state must commit itself to the idea of free research and out of this commitment grows a duty "to prevent the disintegration of this freedom by protecting and supporting it". 61 So, for example, individual lectures are to be protected from active boycotts by audiences or from third parties who attend simply to disrupt. ${ }^{62}$

BVerfGE 35, 202, 221, 233.

BVerfGE 65, 1, 43.

60 References in Von Mangoldt Klein and Starck Das Bonner Grundgesetz art 1 marg no 99-106, art 2 marg no 158-170; Götz Verwirklichung der Grundrechte 35, 58 ff.

61 BVerfGE 35, 79, 114, 116; 43, 242, 267 f; 47, 327, 386; 51, 369, 378; 55, 37, 58 f; 66, 155, 177; 67, 202, 207.

62 BVerfGE 55, 37, 68. 


\subsubsection{The protection of marriage and the family}

The text of article 6 I explicitly requires the protection of marriage and family through the state order. The protection is twofold:

... positively, the duty of the state not only to protect marriage and the family from harm by other forces but also to support them through suitable measures; negatively, the prohibition on the state from damaging or otherwise affecting marriage. 63

\subsubsection{The protection of children}

The recognition of parental responsibility and the rights connected therewith are ... justified in that children need protection and help to develop a responsible personality within society ... . The state must oversee this process and in case of emergency protect the child, which is not yet capable of protecting itself, from damage caused by the abuse or neglect of parental rights. 64

In the final analysis, this concerns the protection of human dignity, as the Court has specifically emphasized. 65

\subsubsection{The protection of mothers}

The claim of mothers to the protection and support of society (article 6 IV) is

... an expression of a constitutional value judgment which is normative for the whole field of private and public law. ${ }^{66}$

\subsubsection{The protection of professional freedom}

63 BVerfGE 6, 55, 76; 24, 104, 109; 55, 114, 126; 87, 1, 35 ff.

64 BVerfGE 24, 119, 144.

65 BVerfGE 24, 119, 144; 72, 155, 170 ff, 174; cf Von Mangoldt Klein and Starck Das Bonner Grundgesetz art 1 marg no 98. 
The Court has derived from article 12 I a legislative duty to create civil protection against the contractual limitation of professional freedom. If the relevant social forces are not equally matched, then state regulations must equalise the situation to secure the protection of the fundamental right. 67

\subsubsection{The protection of property}

The concept of protection also plays a role in decisions relating to property. The leading case is a 1962 judgment ${ }^{68}$ where the right of minority shareholders to a part of the corporate property had to be protected through procedural law from abusive conversion by the majority. In a more recent decision, ${ }^{69}$ a lessee's right of occupation was treated as property for the purposes of article $14 \mathrm{I}$, so that the legislature was obligated to balance the now conflicting property claims of lessee and lessor, having regard to the protectable interests of both parties.

\subsubsection{The protection of German nationals against foreign states}

The organs of the Federal Republic, in particular the Federal government, have a constitutional duty to protect German nationals and their interests from foreign states. ${ }^{70}$ Courts have mentioned the following interests: property, ${ }^{71}$ life and health, ${ }^{72}$ family ${ }^{73}$ and nationality. ${ }^{74}$

\subsection{The justification of protective duties by the Federal Constitutional Court}

\subsubsection{Protective Duties as Commissions}

66 BVerfGE 32, 273, 277; 52, 357, 365; 55, 154, 157; 84, 133, 156; 85, 167, 175.

67 BVerfGE 81, 242, 254 f; cf also BVerfGE 84, 212, 226.

68 BVerfGE 14, 263, 279.

69 BVerfGE 89, 1, 5; on insufficient regard for the property right of the owner cf BVerfGE 37, 132, $140 \mathrm{ff}$; 49, 244, $248 \mathrm{ff}$; 53, 352, $356 \mathrm{ff}$; 68, 361, $367 \mathrm{ff}$; 79, 283, $289 \mathrm{ff}$; see also BVerfGE 7, 230, 234; 71, 230, 246 ff.

70 BVerfGE 55, 349, 364; cf the explicit constitutional regulation in art 3 VI Reich Constitution of 1871 and art 112 II Weimar Reich Constitution.

71 BVerfGE 6, 290, 299; 40, 141, 166; 41, 126, 150, 157 ff, 182.

72 BVerfGE 66, 39, 57 ff; 77, 170, 214 ff.

73 BVerfGE 40, 141, 175.

74 BVerfGE 40, 141, 170. 
The duty of the state to protect human life was expressed for the first time in the First Abortion Judgment, where it was also extended to unborn life. That the right to life extended to the protection of embryonic life was derived from the legislative history of the Basic Law.75-76 From then on, article 2 II 1 was understood not merely as a defensive right, setting boundaries to state activity and requiring respect for human life, but also as a commission to protect human existence from the attacks of third parties. The Court adapted this summary formulation: ${ }^{77}$

For these reasons, the duty of the state to protect every human life can be directly derived from Art. 2 II 1 Basic Law.

This sentence is cited repeatedly in later decisions. ${ }^{78}$

Even before the First Abortion Judgment, the idea of protective duties had been expressed in connection with fundamental civil rights. Conscription was justified by the need of the state to protect the fundamental rights of its citizens. ${ }^{79}$ Later, in another decision concerning military defence, ${ }^{80}$ human dignity, life, freedom and property were named as fundamental rights which the state was required to recognise and protect. Of course, the primary concern here is the threat posed to these rights by external powers, but the duty is formulated in such wide terms that it embraces infringement by third parties within the state, avoiding bringing into play article 87 a IV GG (which covers the rare occasions on which the Federal troops can be mobilised inside the state).

The First Abortion Judgment also uses a second argument, which relies on human dignity, to analyse the state's duty to protect life. ${ }^{81}$ The duty of the state to protect every human life is derived, "additionally, from the explicit [!] requirement of Art. 1 I

75 Cf Von Mangoldt Grundrechte 7 Anlage zum stenographischen Bericht der 9. Sitzung, where he states that "the protection of the right to life extends also to embryonic life".

76 BVerfGE 39, 1, $38 \mathrm{f}$.

77 BVerfGE 39, 1, 41.

78 BVerfGE 46, 160, 164; 53, 30, 57; 56, 54, 73, 80; 77, 170, 214.

79 BVerfGE 38, 154, 167; repeated in BVerfGE 57, 250, 284.

80 BVerfGE 48, 127, 161; 69, 1, 22.

81 BVerfGE 39, 1, 41. 
2 GG".82 "Where human life exists, it enjoys human dignity." In later decisions this twofold justification is partially maintained, but by way of a new and rather vague formulation: "Art. 2 II 1 in connection with Art. 1 I 2 obliges the state to protect every human life."83

The diversity of justifications demonstrates that there are stricter and more generous approaches within the Court to the development of fundamental protective duties. The stricter approach relies on article 1 I 2, which explicitly speaks of the state's duty to protect. Insofar as a fundamental right embraces human dignity, a fundamental protective duty must arise. This is easy to establish in the case of the right to life, since it represents the existential foundation of human dignity. The more generous approach, which does not require human dignity as an argumentative bridge, can be seen in the First Abortion Judgment. The decision on conscription is particularly noticeable, for it names human dignity, life, freedom and property alongside each other as fundamental rights which the state must protect. According to this wide approach, a protective duty can be derived from every fundamental right. We see this, for example, in the decision on competition between trade representatives:

Art. 12 I GG can require the legislature to create provisions protecting the freedom of profession from contractual incursions, namely when a rough equality of bargaining power is lacking. 84

At this point, the Federal Constitutional Court considers it necessary that fundamental values of the Basic Law "and thus at the same time the fundamental principle of the social state" be realised through suitable laws.

\subsubsection{Individual rights which correlate with protective duties}

One question which is closely tied to the source and justification of protective duties is whether they are purely objective legal functions of the state or whether they have corresponding individual rights. It is at least conceivable that these personal rights

82 Thus also BVerfGE 45, 187, $254 \mathrm{f}$.

83 BVerfGE 46, 160, $164 \mathrm{f}$; 49, 24, 53.

84 BVerfGE 81, 242, $254 \mathrm{f}$. 
are narrower in scope than their closest protective duties. ${ }^{85}$ There is clearly an individual right to protection, where the protection of fundamental (or similar) rights is expressly to be found in the text of the Basic Law. This applies especially to the right of human dignity and thus to the core of each right if it is a part of that dignity. It also applies to the special state duties of protection contained in article 6.

Apart from these provisions, the question is quite simply where these individual rights originate. The Court derives them from the objective values which underlie the fundamental rights and which apply to the whole legal order. The Court maintains ${ }^{86}$ without plausibly justifying its opinion - that these objective state duties of protection must correspond to individual rights of the citizen. The Court's reference to the primary significance of fundamental rights is insufficient, because this is to be found in the notion of defensive rights against the state. ${ }^{87}$

The refashioning undertaken by the Court, whereby the objective legal functions of the state to protect security and internal peace are transformed into a collection of individual rights at constitutional level, represents a far-reaching innovation that influences the whole constitutional system, and not least, the separation of powers.

Nonetheless, attempts have been made to characterise this innovation as a rediscovery. ${ }^{88}$ This is clearly wrong. As regards the function of the state in preserving peace and security, there was nothing to rediscover. It was always present in private, criminal and administrative law; it has always been a purpose of the state, exceptionally expressed in programmatic statements (in the Weimar Constitution) or

85 Thus Isensee Das Grundrecht auf Sicherheit 50; Götz Innere Sicherheit 1007, 1016; differently Klein 1994 Deutsches Verwaltungsblatt 489, 495.

86 Eg BVerfGE 49, 89, 141 f - Kalkar; 53, 30, 57 - Mülheim-Kärlich; 77, 180, 214; 77, 281, 402 f; 79, 174, $201 \mathrm{f}$; see also BVerfGE 48, 127, 161; 69, 1, 22: "Within the democratic constitutional order of the Basic Law, the individual fundamental right to protection corresponds with the duty of the citizen to contribute to the securing of this order." See the attemps of motivation by Klein 1994 Deutsches Verwaltungsblatt 491, 493; Unruh Zur Dogmatik der grundrechtlichen Schutzpflichten $58 \mathrm{ff}$.

87 In his comments on the Kalkar Judgment, Rauschning 1980 Deutsches Verwaltungsblatt $831 \mathrm{ff}$ speaks critically of the reconversion of an objective protective duty to an individual fundamental right; Böckenförde 1990 Der Staat 18 f, is also critical.

88 Isensee Das Grundrecht auf Sicherheit 33; idem, Isensee Grundrecht als Abwehrrecht 148, 201 ff, 211 ff; Hermes Schutz von Leben und Gesundheit 147 f; Stern Das Staatsrecht der Bundesrepublik Deutschland 946. 
preserved as a limiting factor to fundamental rights. But, a few exceptions aside, it was quite rightly never a fundamental right itself. Where there is truly an innovation, it is in the concept of individual rights derived from protective duties which can be enforced through the courts against the legislature.

This innovation, which has no roots in the text of the Basic law, emanates from the central role which fundamental rights play in German constitutional thought. The institutional reasons for this are many; they can be located specifically in the creation of a constitutional court and the introduction of the constitutional complaint. Admittedly, many innovations in other areas of law owe their existence to judgments which have decided particular cases, clarified existing rules and thereby created something new. Of course, the legislature is entitled to restrain the courts, if necessary by constitutional amendment. But this is hardly a political reality when the courts are establishing legislative duties and citizens' rights.

This innovation is not rooted in the most recent decisions such as those concerning the protection of life and limb against the dangers of atomic energy or noise pollution (see above II 2 c). Nor did it start within the 1973 decision of the Court concerning the rehabilitation of ex-criminals and rights of reportage on television. Rather, one must look right back to the 1956 Lüth Judgment to see the source of the development. Ostensibly, this judgment did not concern protective duties of the legislature, but dealt only with the judicial interpretation of a statute. In reality, however, it did concern the duty of the state to protect a plaintiff from violations of rights by third parties, and it is often forgotten that even then this protective duty corresponds to an individual right of the plaintiff seeking protection.89 E.-W. Böckenförde convincingly established that "the Lüth Judgment itself has already moved into the second phase of the discovery of the objective value element of fundamental rights", 90 because at this point the unjustified transformation of objective law into individual right had already been carried out. If we had a Supreme Court which simultaneously fulfilled constitutional as well as other judicial functions, as in the USA or Switzerland, this transformation would not have been necessary. In the process of a legitimate civil

89 BVerfGE 7, 198, 206 f; see on this Rüfner Drittwirkung der Grundrechte $226 \mathrm{f}$.

90 Böckenförde 1990 Der Staat 6; cf also Klein 1994 Deutsches Verwaltungsblatt 489. 
action, the fundamental values of the constitution could have influenced the development of private law at the highest level. But in order to appeal to the Federal Constitutional Court, one must establish the violation of an individual constitutional right. 91

\subsubsection{Protective duties and the third-party effect of fundamental rights}

There is an interesting, effectively underground connection requiring exposure between the concept of protective duties which give rise to individual rights and the third-party effect of fundamental rights.

In the case of direct third-party effect of fundamental rights, the third-party is bound by constitutional law in the normal manner. An example of this is article 9 III 2 GG, which, without interposition of a statute, declares void private arrangements which restrict the right to form associations for the advancement and preservation of economic conditions and labour relations. 92 There is no legislative duty here, since the constitution itself creates the necessary duty, although the legislature is naturally free to repeat the constitutional regulation in statute if it so chooses. On the other hand, if the Basic Law read differently, calling upon the legislature to protect the right of everyone and every profession to form associations for the advancement and preservation of economic conditions and labour relations, then this would be a protective duty requiring the legislature to act. The legislature would have to regulate the invalidity of such arrangements, or perhaps create other consequences at civil law, to fulfil the state's protective duty.

Indirect third-party effect requires that general rules of private law be applied within the margin of permissible interpretation in a way which enables binding constitutional

91 BVerfGE 7, 198, $206 \mathrm{f}$ : "According to the requirement of the constitution, the judge must examine whether the private law regulations he is applying are influenced by fundamental rights in the way described. If he ignores these standards and bases his judgment on the omission of this constitutional influence on civil norms, he is not only infringing objective constitutional law by ignoring the objective aspect of constitutional norms, but he - as a holder of public office - is more significantly violating by his judgment the fundamental right which the citizen has even against the judiciary. A constitutional complaint can be raised before the Federal Constitutional Court against such a judgment, regardless of the right to amend the legal error in the civil courts."

92 Scholz Koalititionsfreiheit 1160. 
values to be taken into consideration wherever necessary. This is required because the state has a corresponding protective duty ${ }^{93}$ which the legislature has fulfilled by a general clause to the extent that the judge can interpret and apply the statute in accordance with the Basic Law. The indirect third-party effect of fundamental rights is thus a specific instance of the concept of protective duties, in terms of which the judge must interpret statutes in the light of various protective duties. In other words, a case of indirect third-party effect is present if the legislature enables the state to fulfill a protective duty by passing a general rule of private law which the judge must apply having regard to that protective duty.

This relationship is evident in the 1990 Trade Representative Judgment of the Federal Constitutional Court:94

Even when the legislature omits to create regulative contract law for particular areas of life or types of contract, it does not at all follow that the formation of contracts is vulnerable to the free play of social forces. Rather, the general clauses of private law, above all §§ 138, 242 and 315 BGB, become relevant and operate to prevent disproportionality. Regard must be had to the fundamental rights precisely when these clauses are being made more specific and being applied (BVerfGE 7, 198, 206). The relevant protective function of the constitution is directed in this case at the judge, who realises the basic choices of fundamental rights in situations of disturbed contractual parity using the means available within the private law. This function can be fulfilled in many different ways.

This connection between the concept of protective duties and the third-party effect of fundamental rights has been the subject of comment in the literature for some time.95 It means that fundamental duties of protection are directed in the first instance at the

93 Dürig 1956 Archiv des öffentlichen Rechts 117, 118 f, drew attention to this early on; idem, in Maunz ea Grundgesetz Art 1 marg no 131.

94 BVerfGE 81, 242, 256.

95 Starck 1981 Juristische Schulung 237, 245; correspondingly, Von Mangoldt Klein and Starck Das Bonner Grundgesetz art 1 marg no 270, 272; similarly Badura Persönlichkeitsrechtliche Schutzpflichten 1 ff; Klein 1994 Deutsches Verwaltungsblatt 1640; Unruh Dogmatik der grundrechtlichen Schutzpflichten $71 \mathrm{ff}$. 
legislature, but secondarily at the judiciary in the course of statutory interpretation and application. 96

Isensee 97 overlooks this internal connection because he understands third-party effect literally as the validity of fundamental rights between private individuals. But the theory of indirect third-party effect, correctly understood, simply states that the civil law, which regulates the relationships between individuals, must have regard to the values expressed in the Constitution. 98 While it is true that life and limb, freedom, reputation and property in relationships between legal subjects must be respected, this does not follow from the obligatory force of fundamental rights. Nonetheless, the civil law regulations which protect the interests just listed (for example §§ 823, 1004 BGB) do indeed rest on the same values, 99 producing the picture of human nature which forms not only the foundation of fundamental rights in the relationship between citizen and state but also the basis of private law (and, naturally, of the criminal law as well). Indirect third-party effect refers to the influence of basic value choices, also evident in the catalogue of fundamental rights, on private law through the legislature. These value choices also form the foundation of particular protective duties.

\subsection{Constitutional control of the manner of protection}

In most decisions concerning the fulfilment of protective duties, the Federal Constitutional Court emphasizes that the legislature enjoys a wide margin of discretion. It is

... generally a highly complex question how the state's duty to act and protect, derived from the interpretation of basic choices encapsulated in

96 Thus, clearly, Hesse Grundzüge des Verfassungsrechts marg no 355; Rüfner Drittwirkung der Grundrechte 215, 219 with further references; Hermes 1990 NJurW 1764, 1767; Klein 1994 Deutsches Verwaltungsblatt 492.

97 Isensee Das Grundrecht auf Sicherheit 35 f; appropriately, in contradiction Böckenförde 1990 Der Staat $3 \mathrm{ff}$.

98 Cf Von Mangoldt Klein and Starck Das Bonner Grundgesetz art 1 marg no $271 \mathrm{f}$ with further references.

99 Thus also Rüfner Drittwirkung der Grundrechte 224, in connection with the function of legislation in private law. 
the fundamental rights, is to be realised in particular legislative measures. 100

The Court has decided that the situation must be evaluated, goals and priorities set and conceivable ways and means examined before a legislative solution can be determined. The principles of the separation of powers and democracy require that the final decision, which is often a matter of compromise, be taken by the legislature, since only the legislature is directly legitimated by the people. Its solution can only be assessed to a limited degree by the Court, at any rate when the most valuable legal interests are not relevant. If the case concerns the prevention of specific types of danger, the Court emphasizes the freedom of the legislature (or relevant executive organ) ${ }^{101}$ to decide on the appropriate remedy according to the type, proximity, degree and circumstances of the danger in question. ${ }^{102}$

In its decision relating to the Mülheim-Kärlich nuclear plant, ${ }^{103}$ the Federal Constitutional Court adopted a quite different approach. Having regard to the extraordinary potential for disaster which a nuclear plant represents, and given that it is in the common interest to supply energy, the Court held that the state assumed a partial responsibility for its safety and continued,

... it would accordingly seem necessary that, when assessing the substantive and procedural requirements for the approval of nuclear plants, the constitutional standards should be no less strict than in the case of statutes that infringe fundamental rights.

In the Second Abortion Judgment, which concerned the protection of a particularly significant legal interest, we read, 104

100 BVerfGE 56, 54, $80 \mathrm{f}$, also on what follows; similarly already BVerfGE 39, 1, 44, 51; compare also BVerfG, 1987 Europäische Grundrechte-Zeitschrift $353 \mathrm{f}$.

101 BVerfGE 46, 160, 164.

102 BVerfGE 49, 89, $141 \mathrm{f}$ - Kalkar.

103 BVerfGE 53, 30, 58; similarly already BVerfGE 49, 89, 143.

104 BVerfGE 88, 203, 254. 
The Constitution states protection as a goal, but it does not determine its precise formulation. Nevertheless, the legislature must have regard to the principle of prohibition of insufficiency ...; to this extent it is subject to the control of the Court.

The Traffic Noise Judgment of 1988 states that a protective duty is only infringed where the legislature completely omits to adopt protective measures, or if it has chosen clearly unsuitable or inadequate ones. ${ }^{105}$ A certain flexibility in the intensity of examination makes the Court dependent on prevailing circumstances and the significance of the relevant legal interests. ${ }^{106}$ As regards the circumstances, the most significant factor is the establishment of an adequately argued judgment. 107

These quotations enable the Court to judge more or less generously from case to case. Every case is liable to raise new aspects of the requisite degree of control, which can lead to considerable variation in the Court's judgments. But the general picture one gets of the current jurisprudence is that the Court makes every effort to leave the legislature sufficient discretion and to sanction its manner of protection. In particular, the Court generally makes no requirements as to whether the constitutionally required protection must be achieved by criminal, civil or administrative means. ${ }^{108}$ There are, however, two exceptions. In the First Abortion Judgment, the use of criminal sanctions was required if other means of achieving the effective protection of life were unsuccessful.109 Further, in a decision concerning the negligent causation of losses of liberty through expert opinion, four of the judges derived the requirement that the law relating to civil liability should apply directly from article 2 II 2 GG. 110 But this article would only actually be infringed if it imposed civil liability on all negligent infringements of freedom, and this was hard to establish. The other four judges argued more elegantly from the obligation of judges to apply the law and complained about the uncontrolled use of $\S 823$ (1) BGB.

\footnotetext{
105 BVerfGE 79, 174, $201 \mathrm{f}$.

106 BVerfGE 56, 54, $80 \mathrm{f}$.

107 BVerfGE 77, 170, $214 \mathrm{f}$.

108 Cf Götz Verwirklichung der Grundrechte $61 \mathrm{f}$.

109 BVerfGE 39, 1, 46 ff; cf Müller-Dietz Verfassungsrechtlicher Pönalisierungsgebote 97, 108 ff.
} 


\section{Critique of the Judgments}

\subsection{The justification and nature of protective duties}

\subsubsection{Two doctrinally acceptable ways of deriving protective duties from fundamental rights}

(a) Whenever the Basic Law expressly speaks of "protection" within a fundamental right, as in article $1 \mathrm{I} 2$ and article 6, the individual right to protection is enshrined in the text of the Basic Law. This fact makes it correspondingly more difficult to find protective duties when such protection is not expressly required or only features in a limitation of a right. This explains the frequent attempt of the Federal Constitutional Court to establish protective duties with correlative individual rights by using the concept of human dignity. This works particularly well in the case of human life, which, as we had said, forms the existential basis for the enjoyment of human dignity, but it is more awkward in the case of other fundamental rights. Here, one must isolate the core of each right which the concept of dignity requires, for it is only with regard to this core that an individual right corresponds to a protective duty. This is an exercise which the Court must be qualified to undertake because it is required to examine constitutional amendments to determine whether they accord with article 1, the guarantee of human dignity (compare article 79 III GG).

(b) A parallel approach holds that fundamental rights incorporate the duty of the state to protect them from violation by third parties. This is the main rationale given in numerous decisions and referred to in others (for example the Conscription Judgment). It is unobjectionable to derive this function of the state from the protective aspect of the classical fundamental rights. The interpretation has a close affinity to historical declarations of such rights, including the catalogue of the Weimar Constitution, ${ }^{111}$ and is tied to the state's

110 BVerfGE 49, 304, 323; cf for criticism Starck Praxis der Verfassungsauslegung 218, 220 ff.

111 This contained the following express protective duties: Marriage as the foundation of family and maternity (art 119), youth (art 122 I), undisturbed exercise of religion (art 135), art and science (art 142), memorials to art, history, nature and the landscape (art $150 \mathrm{I}$ ), the labour force (art 157), mental work, the rights of the producer, discoverer and artist (art 158), health, the ability to 
duty to preserve the security of its citizens. But this only amounts to a legal function of the state which, depending on its formulation, content and position in the legal order, could either be a specific constitutional function or a mere programmatic statement.

Thus, there are only two doctrinally acceptable methods of deriving protective duties from fundamental rights:

(a) From article 1 I 2 individual rights to protective duties within the ambit of the protection of human dignity in a narrow sense, along with article 6.

(b) Generally from the fundamental rights, which apart from an individual defensive character have an objective character requiring the state to protect certain legal interests from violations by third parties, without a corresponding individual right.

\subsubsection{The more extensive practice of the Federal Constitutional Court}

The Court has gone beyond both of these acceptable methods.

(a) The method which relies on the protection of human dignity has been extended, as we see from the Second Abortion Judgment in the context of the protection of life. There we read, 112

This protective duty is rooted in Art. 1 I GG, which expressly obliges the state to respect and protect human dignity; the content and thus the extent of the protective duty is made more precise by Art. 2 II GG.

Life is not considered as the essential precondition for the enjoyment of human dignity, which would have been an acceptable solution using the protection of human dignity. Rather, the sentence is formulated in a way that enables one to 
insert any fundamental right in place of article 2 II GG. Human dignity is just a vehicle for the protection of other fundamentally guaranteed legal interests and thus gives rise to an individual right to protection. 113

(b) Without appealing to human dignity, both senates of the Court, in decisions of 1987 and 1988 which relate to the protection of life, 114 have derived a constitutional duty of protection for all areas of the legal system from the objective value choice of article 2 II GG. They have blatantly maintained that the neglect of any area of law by the state can be questioned by way of a constitutional complaint and treated as a violation of the plaintiff's right in article 2 II 1 GG. This amounts to an unjustified mutation of an objective legal value into a personal legal claim.

Both approaches betray weaknesses. Starting with the idea of human dignity as a vehicle, why should the basis of all protective duties be found in one article and the content in some other fundamental right? If the concept of protection appears in article $1 \mathrm{I}$ GG, but not in others, an explanation is owing as to why that protective duty has so much work to do, especially since that article is immune to constitutional amendment and should, therefore, be given a restrictive interpretation. As regards the mutation argument, proof is wholly lacking as to why the value aspect of a fundamental right, which is secondary to its prime significance as a personal (defensive) right, should again give rise to a further personal right. Because this is so completely unconvincing, the Court returns to the vehicle-argument. But if the vehicle-argument had ever been convincing, it would never have developed the mutation-argument. Two bad arguments taken together are no better than one; rather, taken together, they expose the weakness of the argumentation when used in conjunction. 115

112 BVerfGE 88, 203, 251.

113 The vehicle-construct can be found in Isensee Das Grundrecht auf Sicherheit 33, who derives the duty actively to protect fundamental rights from art 1 I 2 GG. Bleckmann 1988 Deutsches Verwaltungsblatt 938, 942; Robbers Sicherheit als Menschenrecht $187 \mathrm{f}$; similarly based on the purpose of the protective duty and the free development of the individual protected by the Basic Law Alexy Theorie der Grundrechte 415 ff; Klein 1989 NJurW 1637.

114 BVerfGE 77, 170, 214 f; 77, 381, 402 f; 79, 174, $201 \mathrm{f}$.

115 Stern Das Staatsrecht der Bundesrepublik Deutschland 945, also writes of a deficit of justification. 


\subsubsection{The defensive route}

Some writers have attempted to seek a way out of these difficulties by denying protective duties any independent standing and interpreting them as a sub-category within the personal defensive function of fundamental rights. The decision on the Mülheim-Kärlich nuclear plant points in this direction. The state, in failing to protect fundamental rights from third-party violation, is itself violating them. One person must suffer what the state does not forbid another from doing. The justification of this position has above all been attempted by Murswiek. ${ }^{116}$ He establishes the necessary connection between classical defensive fundamental rights and fundamental claims to protection from third parties by interpreting protective duties as duties of guarantee which are complementary to fundamental defensive rights.

The state must guarantee the same interests against third parties as fundamental rights guarantee against the state.

Numerous objections to the defensive solution of this problem have been raised. ${ }^{117}$ The most important of these are the following:

(a) Where a specific public law ban on private violations is lacking, it does not follow that there is a duty to tolerate third-party infringements. Within private law there is a general prohibition of harm caused by parties infringing the rights of others. $118 \S 823$ I BGB contains interests also protected by the Constitution: life, bodly integrity, health, freedom and property.

(b) The defensive solution is also methodologically objectionable. The identification of permission or refused prevention of private violations with

116 Murswiek Risiken der Technik $107 \mathrm{ff}$; short and clear also idem, Murswiek 1986 Wirtschaftsverwaltung 179 ff, 182 f; earlier Schwabe Probleme der Grundrechtsdogmatik 213 ff.

117 Cf Alexy Theorie der Grundrechte 415 ff; Klein 1994 Deutsches Verwaltungsblatt 496; Unruh Dogmatik der grundrechtlichen Schutzpflichten $44 \mathrm{ff.}$.

118 Cf Dietlein Die Lehre von den grundrechtlichen Schutzpflichten 46, 50. 
state violations of fundamental interests assumes what is to be proved. 119 The answer to the question whether the state must be credited with the behaviour of a private individual as its own violation of a right logically presupposes not only a duty on the state to act, but also a right against the state of the individual harmed which corresponds to that duty. This requires proof of the degree to which there is a right to state protection from the violations of others. And this is precisely what cannot be derived from fundamental rights, which set limits to state activity, excepting of course those rights - such as article 1 I 2 GG - which do oblige the state to protect and create a corresponding personal claim. ${ }^{120}$

\subsubsection{Reasons for restricting the judgments to the two acceptable approaches}

The Federal Constitutional Court should decide at once whether it is going to hold to the extensive solution in the future or whether it will rely more closely on the text and system of the Constitution and limit the personal right to protection to cases involving human dignity and the core of each fundamental right preserved by dignity. In the latter case, it must be largely satisfied with mere legal functions of the state which do not correspond to personal rights on a constitutional level.

Such an interpretation would conform closely to the Basic Law, and is required by textual, systematic and historical considerations.

(a) Text Apart from named exceptions, the fundamental rights do not speak of personal rights to protection.

(b) System The nature of fundamental rights as "directly binding law" which also binds the legislature (article 1 III GG), necessitates a narrow catalogue of classical defensive rights, (constitutional) judicial review of legislation, and concepts appropriate to legal argument such as those found in the principle of proportionality. Additional functions of fundamental rights result in a corresponding reduction in the legislature's political freedom. This is

119 Stern Das Staatsrecht der Bundesrepublik Deutschland 947 with further references.

120 On the characterisation of art 1 I GG as a fundamental right cf Von Mangoldt Klein Starck Das Bonner Grundgesetz art 1 marg no $24 \mathrm{f}$ with further references. 
particularly significant when the constitutional standards associated with a particular widening of function are vague and unpredictable, as is to a large extent the case with the question of what is to be protected. These uncertainties could work back into the legal nature of the constitution, and the classical defensive aspect of fundamental rights become undermined, if the opinion that defensive rights and protective rights are governed by the same regime became widespread.

(c) History The strength of feeling in the Parliamentary Council that a catalogue of classical fundamental rights should be created must never be forgotten. The reporter Hermann von Mangoldt commented at the end of the consultations that, 121

... the committee decided ... not to adopt a set of fundamental rights in the wide and legally imprecise formulation of Weimar, but rather to attempt to make them clearer and more concrete. A mixture of statements made up for the one part of directly binding law and for the other of legislative programmes, goals in need of statutory regulation, or not simply rights to freedom but the preservation of particular institutions, legal or otherwise, as could be found in the second division of the Weimar Constitution, has led to considerable legal difficulties. As far as possible, these difficulties should be avoided. The intention was, therefore, to formulate the fundamental rights so that they can be seen as directly binding law [emphasis in original], exactly as Art. 1 III expresses it. This law binds the legislature, the administration and the judiciary, and indeed the federation and the Länder in exactly the same manner.

The two articles concerning marriage and family, and the school system and religious education (Art. 6 \& 7) fall to a certain extent outside this framework. Besides containing statements without direct legal effect, they also contain programmatic statements and 
directions to the legislature that cannot be realised, at least in part, without prior detailed regulation. This fault in the structure of the rights catalogue can only be explained by its legislative history. The articles in question were only introduced during the consultations of the main committee, which was not as attentive to the principles governing the construction of this part of the Basic Law.

This quotation clearly demonstrates that the claims to protection in article 6 represent an exception within the catalogue of fundamental rights, which therefore need not be considered further.

The conclusions reached by considering the classical canons of construction is reinforced by a purpose-based approach, deepening the systematic interpretation of the constitution.

The protection of most of the legal interests represented by fundamental rights against third-party incursions is the basic function of the state. It is the preservation of peace in wider sense, and should not be treated as one of many similar purposes. Rather, it is the fundamental function, to the fulfilment of which the state owes its existence. ${ }^{122}$ If it fails to fulfil this function, it will, given time, cease to exist. Anarchy and civil war will break out. The obviously essential nature of the preservation of internal security weighs against the establishment of this function in fundamental rules containing personal rights. ${ }^{123}$

A further state function is the securing of freedom. This is conditional on the securing of internal peace (security). For particular historical reasons, the instrument of the fundamental right, which normally protects the individual from violations by the state, has been developed to guarantee this freedom. ${ }^{124}$ It is only occasionally that fundamental rights specifically require the state to protect the citizen from third

121 See Von Mangoldt Grundrechte 5 and 6.

122 Starck Frieden als Staatsziel $868 \mathrm{ff}$, also on what follows; in particular, see further Isensee Grundrecht als Abwehrrecht 148 ff; Götz Innere Sicherheit 1026.

123 Thus, correctly Sachs, in Stern Das Staatsrecht der Bundesrepublik Deutschland $732 \mathrm{f}$.

124 Link Staatszwecke im Verfassungsstaat 7, 11, refers appropriately to the origin of state goals. See also Böckenförde 1990 Der Staat 34. 
parties. The connection between the protection of freedom and the guarantee of peace and security is expressed in declarations of fundamental rights, in particular in those limitations to the rights which name these legal interests.

The inherent connection between the securing of freedom and keeping the peace does not mean that the citizen has an unwritten fundamental right to peace and security. ${ }^{125}$ This consequence does not flow from the Basic Law precisely because the fundamental rights as individual rights are "hard" constitutional law. They can be enforced before the courts against the administration and indeed against the legislature before constitutional courts. In the same way as claims to social security, rights to peace and security could not be directly enforced at a constitutional level as the classical defensive rights are, simply by virtue of their structure. The infringement of a classical fundamental right must comply formally with the requirement of statutory authority and substantively satisfy the requirement of proportionality. Freedom is already legally valid unless it is limited, but protection must be guaranteed and realised through statute, administration and adjudication. (Of course, it is true that the constitution might protect directly by declaring certain legal acts invalid.) If the protection involves an infringement of another's rights, statutory authority is required; there is no protection where the statute is lacking. To this extent, a fundamental right to protection cannot normally be directly binding, since it is the statute itself which gives rise to the protection. ${ }^{126}$ If there is a valid statute which can be interpreted so that it has a protective effect - as a protective norm in administrative law for example, or the so-called third-party effect in private law - then the fundamental right can have influence through the medium of this statute.

Even if earlier catalogues of fundamental rights did include aspects of security, we must not forget that they - above all the French declaration of 1789 - did not contain personal rights which could be enforced before the courts. Rather, these rights, which functioned as guarantees both of freedom and of security, were programmatic statements in the service of general state goals. ${ }^{127}$ At best, statutory rights could be

125 Otherwise Isensee Grundrecht als Abwehrrecht 187.

126 Thus also Isensee Grundrecht als Abwehrrecht 189; Klein 1994 Deutsches Verwaltungsblatt 491, 494 f; Unruh Dogmatik der grundrechtlichen Schutzpflichten 23 f.

127 Thus, appropriately Böckenförde 1990 Der Staat 23, note 92; Unruh Dogmatik der 
enforced before courts against the administration. For this reason, the use of fundamental rights - insofar as they represent classical defensive rights against the state - as a standard for the judicial assessment of statutes must be seen as a farreaching innovation.

\subsubsection{The consequences of reducing the judgments to the two acceptable approaches}

If the Federal Constitutional Court were to restrict itself to recognising a personal right to protection only in those few cases involving the guarantee of human dignity, and spoke in other cases of mere protective functions of the state, this would restrict the admissible constitutional complaints to those where an infringement of human diginity could reasonably be alleged. Whether this would lead to a reduction in the numbers of complaints seeking to establish protection would remain to be seen, particularly since efforts would be made to expand the concept of dignity and the Court would have to justify drawing narrower boundaries to this concept than plaintiffs would like. But there is no doubt that clarity would emerge over time.

Another factor must be taken into consideration. Even if it became unnecessary for the Court to hear many of the complaints concerning statutory protection because they would not impinge on the protection of dignity, one could not avoid considering whether the legislature had conformed to the objective requirements of fundamental rights in the context of norm-review procedures. ${ }^{128}$ The protective functions of the state would then have to be divided into those which represented clearly defined commissions at a constitutional level and those which were mere programmatic statements. The latter are not suitable standards by which a constitutional court can establish unconstitutional legislative omissions. ${ }^{129}$ Constitutional legislative

grundrechtlichen Schutzpflichten 41.

128 For personal rights see Klein 1994 Deutsches Verwaltungsblatt 493; Unruh Dogmatik der grundrechtlichen Schutzpflichten 65. State protective duties without corresponding personal rights ought generally to exclude the specific norm control whenever the court referring the matter considers a legislative omission to be unconstitutional. This is because art 100 I GG presupposes the existence of a statute. The situation would be different if the court considers an existing statute to be insufficiently protective, and considers this relative omission to be unconstitutional. (Cf Benda and Klein Lehrbuch des Verfassungsprozeßrechts marg no 726 f).

129 Benda and Klein Lehrbuch des Verfassungsprozeßrechts marg no 428; on what follows marg no $430 \mathrm{ff}$. 
commissions and the degree of their precision must be demonstrated on a case to case basis. One can point by way of comparison to rights to financial support which the Court has (still?) been very hesitant to derive from particular constitutional and factual constellations. The claim to the financing of private schools is an example of this. ${ }^{130}$

The restriction of the jurisprudence in this whole area of protective duties would return greater discretion to the legislature, so that it could once again fulfil its responsibility in shaping of society within the framework of classical rights. A demonstration of the need for this can be found in the Court's 26 May 1993 decision, ${ }^{131}$ in which a lessee was granted a right to protection against a lessor on the basis of article 14 I 1 GG. According to the judgment, the legislature,

to fulfill its duty arising from Art. 14 I 2 GG, must fashion, delimit and define the conflicting property interests so that both are suitably protected.

The Court had justified the lessee's rights as recently as 1989 by reference to the social state in the light of the lessor's fundamental right of property. ${ }^{132}$ In 1993, by application of the doctrine of duties of protection, the lessee's rights were upgraded to a matter of fundamental rights which must be balanced with the rights of the lessor. The consequence of this - unnoticed at the time - is that every reduction in the standard of lessee protection is an infringement of fundamental rights requiring constitutional justification. ${ }^{133}$ But the protection of lessees really raises questions of social justice which fall within the competence of the legislature according to article 14 II and 20 I GG. Parliament must be free to decide on these matters within the framework of the protection of property, because only it is politically accountable for the fashioning of society and, among other matters, for the statutory regulation of private building for the purposes of letting.

130 BVerfGE 75, 40, 65; on this problem Von Mangoldt Klein and Starck Das Bonner Grundgesetz art 1 marg no 119.

131 BVerfGE 89, $1,5$.

132 BVerfGE 79, 292, 302 f; 68, 361, 368.

133 Depenheuer 1993 NJurW 2561, 2564, refers appropriately to this. Hesse Verfassungsrecht und Privatrecht $23 \mathrm{ff}$, is generally critical. 
Parliament could be restored to this position, if only the Court would restrict personal rights to protection to the narrow boundaries of article 1 I GG and more thoroughly justify those obligatory protective functions of the legislature which go beyond mere programmatic statements. The divisional courts would recover a higher degree of power in the interpretation and application of statutes which protect legal interests sometimes, indeed, in favour of that protection.

\subsection{Controlling the manner of protection}

The following considerations regarding the manner of protection and its regulation by the judiciary are significant in two ways.

First, constitutional standards for the manner of protection must be developed for the small group of personal rights to protection in articles 1 I and 6 GG and for the legal protective duties which can be derived from fundamental rights. To establish that the state is obliged to protect, or even that there is a right to protection, is only half the story: the other half is the manner of protection. Fundamental protective duties do not contain detailed directions on this matter, 134 but we must still consider whether they contain at least a minimum standard of protection, for a right to protection without any criteria for the manner of its fulfilment would be empty and a cheap opportunity for the legislature to pass statutory propaganda while claiming to protect some interest.

Secondly, the difficulty one encounters in trying to find constitutional standards for the control of the manner of protection further supports the critique of the unhindered acceptance of fundamental protective duties by the Federal Constitutional Court.

\subsubsection{Criteria for the manner of protection}

In its judgments concerning the state's protective duties, the Court has emphasised the legislative discretion to determine the manner of protection. But, despite all attempts at judicial restraint, the various formulae adopted and the practice so far (see above 
2.4) reveal a certain degree of unpredictability. This need not be intrinsic to the issue: it may well flow from the undeveloped state of suitable criteria offered by Court. It is probably also connected with the experimental and ever-expanding nature of the jurisprudence in this area.

A number of possible criteria can be listed, some of which flow from what has already been mentioned, others of which need further justification.

(a) Seen as a whole, the manner of protection must not render the requirement of protection illusory. 135

(b) The legislature is not constitutionally obliged to provide optimal protection, for this would raise the standards of protection ever higher ${ }^{136}$ and subject the manner of protection totally to constitutional review.

(c) Protection must respect the principles of the rule of law, 137 that is infringements of third-party rights must have statutory authority. ${ }^{138}$

(d) The legislature, engaged in protection, is bound to the principle of proportionality. Since protection from third parties regularly infringes their fundamental rights, the principle of proportionality which must be respected in that case also influences the mode of protection.

\subsubsection{The significance of the principle of proportionality}

The principle of proportionality (or the prohibition of excess) has proved a reasonable standard of examination for the constitutionality of state infringements of civil rights. Along with its sub-principles - suitability, necessity and proportionality in strict sense

- it produces comprehensible solutions. Of course, there are still obscurities which

134 Thus also Klein 1994 Deutsches Verwaltungsblatt 495.

135 See Starck Praxis der Verfassungsauslegung $86 \mathrm{ff}$.

136 On this point Böckenförde 1990 Der Staat 13, 29, is quite rightly critical.

137 On this see generally Sachs, in Stern Das Staatsrecht der Bundesrepublik Deutschland 738.

138 See on this above all Wahl and Masing 1990 Juristenzeitung 553, 555 ff; see also Klein 1994 Deutsches Verwaltungsblatt 491, 494 f; Unruh Dogmatik der grundrechtlichen Schutzpflichten 
restrict legislative freedom (for example, whenever the Court examines factual assessments and predictions). ${ }^{139}$

How can the prohibition of excess be used as a standard for the manner of protection? Some writers have matched the prohibition of excess to a prohibition of insufficiency which should govern the statutory expression of protective duties, ${ }^{140}$ and this has been adopted by the Court with their approval. ${ }^{141}$ It seems at first sight as though the prohibition of insufficiency limits the freedom of the legislature from the opposite side from the prohibition of excess, trapping the legislature between these two prohibitions. If one examines the relationship between the prohibition of excess as the boundary of permissible infringement and the prohibition of insufficiency as minimum protection more closely, however, the following points emerge. 142

(a) As regards the legal interest to be protected, each limitation of a fundamental right presupposes the existence of a legal interest worthy of protection. In the case of a protective duty, the protection of a legal interest is constitutionally necessary.

(b) The means adopted by the legislature must be suitable to the protection. Unsuitable means contravene not only the prohibition of excess, since they limit freedom without protecting a legal interest, but also infringe the prohibition of insufficiency, since for the same reason they do not fulfill the protective duties of the state.

(c) The infringement of fundamental rights must be necessary, that is the legislature must be satisfied with the mildest means that are effective. As far as protection is concerned, every excessive measure restrictive of freedom must be avoided.

$23 \mathrm{f}$.

139 See in particular BVerfGE 50, 290, 333 with further references.

140 Canaris 1984 Archiv für die civilistische Praxis 201, 223 ff; idem "Grundrechtswirkungen und Verhältnismäßigkeitsprinzip in der richterlichen Anwendung und Fortbildung des Privatrechts", in Canaris 1989 Juristische Schulung 161, 163 f; Götz Innere Sicherheit 1025 ff; Isensee Grundrecht als Abwehrrecht 191.

141 Cf BVerfGE 88, 203, 254.

142 See on this Starck Praxis der Verfassungsauslegung 88 f; cf also Hain 1993 Deutsches Verwaltungsblatt 982 ff; Unruh Dogmatik der grundrechtlichen Schutzpflichten 83 ff. 
(d) Proportionality in the strict sense, or the reasonableness of the infringement, means that protection reaches its limits when it requires an infringement that is no longer reasonable, that is, where the protection of the relevant legal interest no longer justifies the infringement of freedom.

These thoughts on the reverse of the principle of proportionality demonstrate the strength of reasoning which is required by the necessity to have regard to the possible infringement of third-party rights for the corresponding manner of protection.

There is, therefore, an internal connection between the prohibition of excess in the case of a limitation of fundamental rights and the prohibition of insufficiency in the case of the required manner of protection. Is it then correct to say that the degree of controlling power exercised by the constitution and the corresponding legislative freedom are similar in both cases? If a regulation is unsuited to the protection of legal interest, it may not limit freedom. Thus far the preconditions are identical. As regards necessity, we also begin by looking at the relevant legal interest, asking whether a measure less restrictive of freedom would suffice for its protection. It is often hard to judge whether a measure is suitable and necessary, since that involves the assessment of empirical data and predictions. These uncertainties are identical whether one seeks to establish that protection is sufficient or an infringement is too excessive. If we want to know whether a particular infringement is necessary and imagine other less restrictive infringements, we must examine these in turn for their appropriateness in protecting whatever legal interest the legislature had in mind. The uncertainties surrounding empirical data increase the legislative freedom, which is as wide in the case of infringements as it is in the case of protection. The constitutional protective duties of the legislature and the judicial application of statutes, both of which carry responsibility for the stability of society, draw attention to the limits of fundamental rights. The principle of proportionality in the strict sense establishes a relationship between the value of protection and the hindrance of freedom. The reasonability of protection is determined by considering the infringement of freedom, which may mean that the protection of a legal interest must be neglected if there is no 
reasonable infringement that will do the protecting. But even here the state's duty to protect must be taken seriously.

\subsubsection{Legislative omissions}

Where a statute infringes the rights of third parties in order to protect individual legal interests, the Federal Constitutional Court can examine it to determine whether the protection is sufficient with regard to the criteria of the principle of proportionality. It need not state positively how the state is to do the job of protecting. But, if a statute is lacking, the court cannot examine the manner of protection. The legislature must decide whether and how it will protect, whether by infringement or other measures. The Court can establish only that a protective duty exists, and, where appropriate, identify a corresponding right in the plaintiff, but it cannot go into further detail. Thus, the claim to protection is a fundamental right which does not bind directly, and which lies outside the structure of the Basic Law. In fields which have not yet been the subject of statutory regulation, it is also insufficient to point to the power of the Court to pass protective regulations as a matter of enforcement ( $\S 35$ BVerfG) in order to prove the directness of an obligation. If this were to happen, the Court would move to the heart of legislative political discretion, for it would develop novel regulations for a particular issue involving protection.

The Federal Constitutional Court has no choice but to urge the legislature to fulfil its duty of protection. As regards the manner of protection, the Court must restrict itself to general comments along the lines of the above standards. It is only when a legislative attempt to protect some interest lies before the Court that its constitutionality can be examined. ${ }^{143}$

\subsection{Conclusions}

Contrary to article 1 III GG, claims to protection cannot be directly binding law. They presuppose legislation.

143 Cf also Klein 1994 Deutsches Verwaltungsblatt 496: "Was, um der Schutzpflicht zu genügen, zu tun ist, läßt sich allerdings desto genauer beschreiben, je dichter das Netz bereits vorhandener 
If statutory protection is connected with infringements of third-party fundamental rights, the principle of proportionality can be adopted to test whether the protection is effective.

Insofar as protection can be achieved without infringements of rights, one must attempt to test the effectiveness of protection by some other means.

Where the legislature omits to protect at all, the Constitutional Court must limit itself to establishing the existence of a duty and to querying its non-fulfilment. It may not pass protective regulations or impose a duty to pass specific regulations.

Where general statutory norms apply, protective duties can be realised through the socalled indirect third-party effect of fundamental rights. In its reaching its decision, the Federal Constitutional Court is responsible for:

(a) preserving the political discretion of the legislature in protecting interests, and

(b) remembering the structural distinction between "hard" defensive rights and "soft" protective duties in order to prevent the erosion of the directly binding nature of defensive rights.

Normierungen gewoben ist." 


\section{Bibliography}

Alexy Theorie der Grundrechte

Alexy R Theorie der Grundrechte (Nomos-Verlag Baden-Baden 1985) 548

Badura Persönlichkeitsrechtliche Schutzpflichten

Badura P "Persönlichkeitsrechtliche Schutzpflichten des Staates im Arbeitsrecht" in Gamillscheg F (ed) Sozialpartnerschaft in der Bewährung: Festschrift für Karl Molitor zum 60. Geburtstag (Beck München 1988) 418

Benda and Klein Lehrbuch des Verfassungsprozeßrechts

Benda E and Klein E Lehrbuch des Verfassungsprozeßrechts (Müller Heidelberg 1991)

Bleckmann 1988 Deutsches Verwaltungsblatt

Bleckmann A "Neue Aspekte der Drittwirkung der Grundrechte" 1988 Deutsches Verwaltungsblatt 938-942

Böckenförde 1990 Der Staat

Böckenförde E-W "Grundrechte als Grundsatznormen" 1990 Der Staat 1-34

Canaris 1989 Juristische Schulung

Canaris CW "Grundrechtswirkungen und Verhältnismäßigkeitsprinzip in der richterlichen Anwendung und Fortbildung des Privatrechts" 1989 Juristische Schulung 161

Canaris 1984 Archiv für die civilistische Praxis

Canaris CW "Grundrechte und Privatrecht" 1984 Archiv für die civilistische Praxis 201-223 
Classen 1987 Jahrbuch des öffentlichen Rechts

Classen CD "Die Ableitung von Schutzpflichten des Gesetzgebers aus Freiheitsrechten - ein Vergleich von deutschem und französischem Verfassungsrecht sowie der Europäischen Menschenrechtskonvention" 1987 Jahrbuch des öffentlichen Rechts 29

Depenheuer 1993 NJurW

Depenheuer O "Der Mieter als Eigentümer?" 1993 Neue Juristische Wochenschrift 2561

Dicey Study of the Law of the Constitution

Dicey AV Introduction to the Study of the Law of the Constitution 10th ed (Macmillan London 1959)

Dietlein Die Lehre von den grundrechtlichen Schutzpflichten

Dietlein J Die Lehre von den grundrechtlichen Schutzpflichten (Duncker \& Humblot Berlin 1992) 250

Dürig 1956 Archiv des öffentlichen Rechts

Dürig G "Der Grundrechtssatz von der Menschenwürde" 1956 Archiv des öffentlichen Rechts 117

Duverger and Sfez Staatsbürgerlichen Rechte in Frankreich

Duverger $\mathrm{M}$ and Sfez L "Die staatsbürgerlichen Rechte in Frankreich" in Bettermann KA Nipperdey HC and Scheuner (eds) Die Grundrechte: Handbuch der Theorie und Praxis der Grundrechte vol I/2 (Duncker \& Humblot Berlin 1967)

Götz Verwirklichung der Grundrechte

Götz V "Die Verwirklichung der Grundrechte durch die Gerichte im Zivilrecht" in Heyde W and Starck C (eds) Vierzig Jahre Grundrechte in ihrer Verwirklichung durch die Gerichte (Beck München 1990) 221 
Götz Innere Sicherheit

Götz V "Innere Sicherheit" in Isensee J and Kirchhof P (eds) Handbuch des Staatsrechts (Müller Heidelberg 1988)

Hain 1993 Deutsches Verwaltungsblatt

Hain K-E "Der Gesetzgeber in der Klemme zwischen Übermaß- und Untermaßverbot?" 1993 Deutsches Verwaltungsblatt 982

Hermes 1990 NJurW

Hermes G "Grundrechtsschutz durch Privatrecht auf neuer Grundlage?" 1990 NJurW 1764

Hermes Schutz von Leben und Gesundheit

Hermes G Das Grundrecht auf Schutz von Leben und Gesundheit: Schutzpflicht und Schutzanspruch aus Art. 2 Abs. 2 Satz 1 GG (Müller Heidelberg 1987) 307

Hesse Grundzüge des Verfassungsrechts

Hesse K Grundzüge des Verfassungsrechts der Bundesrepublik Deutschland 18th ed (Müller Heidelberg 1991) 319

Hesse Verfassungsrecht und Privatrecht

Hesse K Verfassungsrecht und Privatrecht (Müller Heidelberg 1988) 44

Isensee Grundrecht als Abwehrrecht

Isensee "Das Grundrecht als Abwehrrecht und als staatliche Schutzpflicht" in Isensee and Kirchhof (eds) Handbuch des Staatsrechts der Bundesrepublik Deutschland (Müller Heidelberg 1992) 1315

Isensee Grundrecht auf Sicherheit Isensee J Das Grundrecht auf Sicherheit (De Gruyter Berlin 1983) 60 
Kägi Dreiteilung zur umfassenden Gewaltenteilung

Kägi W "Von der klassischen Dreiteilung zur umfassenden Gewaltenteilung" in Festschrift für Hans Huber (1961)

Klein 1989 NJurW

Klein E "Grundrechtliche Schutzpflichten des Staates" 1989 NJurW 1633-1636

Klein 1994 Deutsches Verwaltungsblatt

Klein HH "Die grundrechtliche Schutzpflicht" 1994 Deutsches Verwaltungsblatt 489-495

\section{Link Staatszwecke im Verfassungsstaat}

Link C "Staatszwecke im Verfassungsstaat - nach 40 Jahren Grundgesetz: Berichte und Diskussionen auf der Tagung der Vereinigung der Deutschen Staatsrechtslehrer in Hannover vom 4. bis 7. Oktober 1989" in Veröffentlichungen der Vereinigung der Deutschen Staatsrechtslehrer 48 (De Gruyter Berlin 1990) 363

Link Herrschaftsordnung und bürgerliche Freiheit

Link C Herrschaftsordnung und bürgerliche Freiheit: Grenzen der Staatsgewalt in der älteren deutschen Staatslehre (Boehlau Wien 1979) 396

Luchaire La protection constitutionnelle des droits et des libertés

Luchaire F La protection constitutionnelle des droits et des libertés (Nebent France 1987)

Maunz ea Grundgesetz Art 1 marg no 131

Maunz T ea Grundgesetz: Kommentar (Beck München 1958)

Montesquieu De l'esprit des lois

Montesquieu C De l'esprit des lois XI (1748) (Gonzague Truc - Classiques Garnier Paris sa) 
Müller-Dietz Verfassungsrechtlicher Pönalisierungsgebote

Müller-Dietz H "Zur Problematik verfassungsrechtlicher Pönalisierungsgebote" in Jescheck H-H (ed) Festschrift für Eduard Dreher zum 70 Geburtstag am 29. April 1977 (De Gruyter Berlin 1977) 799

Murswiek 1986 Wirtschaftsverwaltung

Murswiek D "Zur Bedeutung der grundrechtlichen Schutzpflichten für den Umweltschutz" 1986 Wirtschaftsverwaltung 179-182

Murswiek Risiken der Technik

Murswiek D Die staatliche Verantwortung für die Risiken der Technik: verfassungsrechtliche Grundlagen und immissionsschutzrechtliche Ausformung (Duncker \& Humblot Berlin 1985) 428

Ossenbühl Tatsachenfeststellungen und Prognoseentscheidungen

Ossenbühl F "Die Kontrolle von Tatsachenfeststellungen und Prognoseentscheidungen durch das Bundesverfassungsgericht" in Starck C (ed) Bundesverfassungsgericht und Grundgesetz Festgabe aus Anlass des 25 jährigen Bestehens des Bundesverfassungsgerichts I (Mohr Tübingen 1976)

Rauschning 1980 Deutsches Verwaltungsblatt

Rauschning D "Kalkar Judgement" 1980 Deutsches Verwaltungsblatt

Robbers Sicherheit als Menschenrecht

Robbers G Sicherheit als Menschenrecht: Aspekte der Geschichte, Begruendung und Wirkung einer Grundrechtsfunktion (Nomos-Verlag BadenBaden 1987) 292

Röllecke and Starck Bindung des Richters Röllecke G and Starck C "Die Bindung des Richters an Gesetz und Verfassung" in Veröffentlichungen der Vereinigung der deutschen Staatsrechtslehrer 34 (De Gruyter Berlin 1976) 352 
Rönne and Zorn Das Staatsrecht der Preußischen Monarchie

Rönne L von and Zorn PKL Das Staatsrecht der Preußischen Monarchie 4th ed (Brockhaus Leipzig 1882)

Rüfner Drittwirkung der Grundrechte

Rüfner W "Drittwirkung der Grundrechte" in Selmer P (ed) Gedächtnisschrift für Wolfgang Martens (De Gruyter Berlin 1987) 909

Schlette Die verwaltungsgerichtliche Kontrolle von Ermessensakten Schlette V Die verwaltungsgerichtliche Kontrolle von Ermessensakten in Frankreich: eine Analyse der Rechtsprechung des Conseil d'Etat zu Inhalt und Umfang des pouvoir discretionnaire der französischen Verwaltungsbehoerden, unter besonderer Beruecksichtigung der neueren Entwicklungen (NomosVerlag Baden-Baden 1991) 408

Scholz Koalititionsfreiheit

Scholz R "Koalititionsfreiheit" in Isensee J and Kirchhof P (eds) Handbuch des Staatsrechts der Bundesrepublik Deutschland VI (Müller Heidelberg 1989)

Schwabe 1979 Deutsches Verwaltungsblatt Schwabe J 1979 Deutsches Verwaltungsblatt 667

Schwabe Probleme der Grundrechtsdogmatik Schwabe J Probleme der Grundrechtsdogmatik (Schadel Darmstadt 1977) 482

Starck 1988 Archiv des öffentlichen Rechts

Starck C "Der Schutz der Grundrechte durch den Verfassungsrat in Frankreich" 1988 Archiv des öffentlichen Rechts 632-633

Starck 1981 Juristische Schulung Starck C "Die Grundrechte des Grundgesetzes" 1981 Juristische Schulung 237245 
Starck Europas Grundrechte im neuesten Gewand

Starck C "Europas Grundrechte im neuesten Gewand" in Festschrift für Hans Huber (Stämpfli Bern 1981) 699

Starck Frieden als Staatsziel

Starck C "Frieden als Staatsziel" in Börner B (ed) Einigkeit und Recht und Freiheit: Festschrift für Karl Carstens zum 70. Geburtstag am 14. Dezember 1984 (Heymann Köln 1984)

Starck Verfassungsgerichtsbarkeit

Starck C "Vorrang der Verfassung und Verfassungsgerichtsbarkeit" in Starck C and Weber A (eds) Verfassungsgerichtsbarkeit in Westeuropa I (Nomos-Verlag Baden-Baden 1986)

Starck Der demokratische Verfassungsstaat

Starck C Der demokratische Verfassungsstaat: Gestalt, Grundlagen, Gefährdungen (Mohr Tübingen 1995) 439

Starck Praxis der Verfassungsauslegung

Starck C Praxis der Verfassungsauslegung (Nomos-Verlag Baden-Baden 1994) 320

Stern Das Staatsrecht der Bundesrepublik Deutschland

Stern K (ed) Das Staatsrecht der Bundesrepublik Deutschland (Beck München 1977)

Stolleis Geschichte des öffentlichen Rechts in Deutschland Stolleis M Geschichte des öffentlichen Rechts in Deutschland (Beck München 1988)

Unruh Zur Dogmatik der grundrechtlichen Schutzpflichten

Unruh P Zur Dogmatik der grundrechtlichen Schutzpflichten (Duncker \& Humblot Berlin 1996) 120 
Von Mangoldt Grundrechte

Von Mangoldt H "Schriftlicher Bericht I. Die Grundrechte" in Parlamentarischer Rat Anlage zum stenographischen Bericht der 9. Sitzung

Von Mangoldt Klein and Stark Das Bonner Grundgesetz

Von Mangoldt H Klein F and Starck C Das Bonner Grundgesetz 4th ed (Vahlen München 1985)

Von Rotteck and Welcker (eds) Das Staats-Lexicon

Von Rotteck K and Welcker K (eds) Das Staats-Lexicon: Encyklopaedie der sämmtlichen Staatswissenschaften für alle Stände; in Verbindung mit vielen der angesehensten Publicisten Deutschlands vol V (Brockhaus Leipzig 1856-1866)

Von Wolff Jus Naturae methodo scientifica pertractatum

Von Wolff C "Jus Naturae methodo scientifica pertractatum" in Von Wolff C and Von Ecole J (eds) Gesammelte Werke (Olms Hildesheim 1962) vol I 1764

Vorländer (ed) Metaphysik der Sitten

Vorländer K (ed) Metaphysik der Sitten, Rechtslehre 1797 4th ed (Meiner Leipzig 1922)

Wahl and Masing 1990 Juristenzeitung

Wahl R and Masing J "Schutz durch Eingriff" 1990 Juristenzeitung 553-555

Zachariä Deutsches Staats- und Bundesrecht

Zachariä HA Deutsches Staats- und Bundesrecht 3rd ed (Vandenhöck \& Ruprecht Göttingen 1865-1867) 